\title{
RANCANG BANGUN MENARA DEAMMONIASI UNTUK PERBAIKAN MUTU LATEKS SKIM
}

\author{
Construction Design of Deammoniation Tower to Improve \\ Skim Latex Quality \\ Henry PRASTANTO \\ Pusat Penelitian Karet, Jalan Salak No 1 Bogor 16151
}

Diterima tgl. 16 Agustus 2011/Disetujui 25 Oktober 2011

\begin{abstract}
Latex skim is a by-product in the centrifuge latex production. Its dry rubber content is very low but the ammonia levels is quite high. The reducing of ammonia content is critical step and should be carried out in order to reduce coagulant cost. The reduction of ammonia content in industries is commonly done by packed bed column with specific design which depends on many factors, such as liquid properties, deammoniation rate, and separation efficency to be achieved. In this research, the deammoniation tower was designed for $1500 \mathrm{~L} /$ hour of skim latex with initial ammonia content of $0.5 \% \mathrm{w} / \mathrm{w}$ to produce skim latex content of $0.25 \% \mathrm{w} / \mathrm{w}$. The tower dimension was designed by using the principal of mass transfer and mass balance which has been commonly used in chemical engineering operation.
\end{abstract}

Keywords: Skim latex, deammoniation tower, packed bed system

\section{Abstrak}

Lateks skim adalah hasil samping dalam produksi lateks pekat pusingan, kadar karet keringnya sangat rendah dan mengandung amoniak yang cukup tinggi. Penurunan kadar amoniak merupakan langkah yang sangat penting dan harus dilakukan untuk mengurangi biaya bahan penggumpal. Penurunan kadar amoniak di industri pada umumnya dilakukan dengan menara bahan isian dengan perancangan khusus yang tergantung pada banyak faktor misalnya sifat cairan, kecepatan penguapan amoniak, dan efisiensi penguapan yang diinginkan. Dalam penelitian ini menara deammoniasi dirancang untuk kapasitas lateks skim $1500 \mathrm{~L} / \mathrm{jam}$ dengan kadar amoniak awal $0,5 \% \mathrm{~b} / \mathrm{b}$ untuk menghasilkan lateks skim dengan kadar amoniak $0,25 \% \mathrm{~b} / \mathrm{b}$. Dimensi menara dirancang menggunakan prinsip perpindahan massa dan neraca massa yang umum digunakan dalam operasi teknik kimia.

Katakunci: Lateks skim, menara deammoniasi, sistem bahan isian

\section{PENDAHULUAN}

Lateks skim adalah lateks dengan kadar karet kering yang sangat rendah, merupakan hasil samping pada pembuatan lateks pekat dengan metode sentrifugasi. Volume yang dihasilkan sebanding dengan volume lateks pekat yang diproduksi. Lateks skim masih mengandung partikel karet dengan kadar karet kering antara 4 - 8\% (Blackely, 1966).

Saat ini Indonesia paling tidak memiliki 15 pabrik lateks pekat yang tersebar di 7 propinsi. Produksi rata-rata per tahun dari seluruh pabrik tersebut adalah sekitar 42480 ton. Kapasitas terpasang pada seluruh pabrik tersebut adalah sekitar 200000 ton per tahun. Volume lateks skim yang dihasilkan bisa dikatakan sebanding dengan volume lateks pekat yang dihasilkan. Jika produksi lateks skim setahun sekitar 42480 ton maka akan diperoleh karet skim kering sebanyak 2549 ton per tahun (Harris et al., 2010).

Selama ini sebagian besar pabrik masih membiarkan lateks skim tersebut di kolam penampungan dan dibiarkan menggumpal secara alami sehingga karet skim yang diperoleh berbau busuk, sukar digiling atau dilembarkan dan berwarna 
gelap. Harga koagulum tersebut sangat rendah yaitu sekitar 20 - 30\% dari harga SIR 20 , atau dalam keadaan kering $100 \%$ harganya sekitar $40 \%$ harga SIR 20. Karena sukar digiling, selama ini karet skim alami tersebut digunakan sebagai pencampur karet alam dalam pembuatan barang jadi karet berharga murah yang tidak memerlukan spesifikasi dalam perdagangannya. Sisa limbah penggumpalan karet skim tersebut juga mengeluarkan bau busuk yang sangat mencemari lingkungan sekitar. Kadar N-Amoniak limbah cairnya biasanya juga lebih tinggi dari ambang batas yang diijinkan.

Deammoniasi atau penurunan kadar amoniak lateks skim sebelum diolah sangat penting karena menyangkut mutu karet skim yang dihasilkan dan biaya bahan penggumpal yang harus dikeluarkan. Noordin (1993) telah melakukan penelitian dan perancangan alat deammonasi lateks skim dengan menggunakan rotating disc system. Alat ini dirancang untuk menggantikan menara deammoniasi komersial sebelumnya yaitu dengan sistem slottedplate-column yang dinilai kurang efisien dan kurang ekonomis karena harus sering dibersihkan. Prinsip dari alat adalah dengan memperluas kontak antara udara peniup dan lateks skimnya. Alat ini berupa silinder tegak dan memiliki ukuran tinggi 3 $\mathrm{m}$ dan diameter $1,5 \mathrm{~m}$. Dalam silinder terdapat ruangan bersekat dan bertingkat. Dalam setiap ruangan tersebut terdapat plat yang menempel pada as dan diputar dengan motor. Lateks dipompa ke atas alat kemudian mengalir dari sekat paling atas ke bawah sedang-kan udara peniup mengalir dari dasar ke atas dengan alat peniup berupa blower. Putaran plat menyebabkan lateks skim yang terkumpul diatas plat terlempar ke arah dinding ruangan bersekat dan memiliki dalam ukuran yang kecil sambil berkontak dengan udara peniup. Noordin (1993) menjelaskan bahwa menara deammoniasi dengan sistem slotted-plate column hanya mampu menguapkan amoniak sebanyak $45 \%$ saja, sedangkan menara deammoniasi rancangannya mampu menguapkan amoniak hingga $70 \%$.

Alfa et al. (1998) telah melakukan penelitian penurunan kadar amoniak dengan pengipasan dan pengadukan. Namun titik berat penelitian ini lebih kepada pengolahan karet skim setelah kadar amoniaknya diturunkan. Penelitian penurunan kadar amoniak dalam skim juga telah dilakukan oleh Solichin dan Anwar (2008). Metode penurunan kadar amoniak dalam penelitian tersebut dilakukan dengan cara pengadukan lateks skim dan aerasi. Dengan metode pengadukan selama 8 jam kadar amoniak dapat diturunkan dari $0,598 \%$ menjadi $0,317 \%$, sehingga jumlah amoniak yang dapat diuapkan sebanyak $47 \%$. Sebaliknya dengan metode aerasi atau penggelembungan udara peniup ke dalam lateks skim selama 8 jam kadar amoniak dapat diturunkan dari $0,598 \%$ menjadi $0,483 \%$, sehingga jumlah amoniak yang berhasil diuapkan adalah sekitar 19\%.

Penelitian ini bertujuan untuk merancang menara deammoniasi yang biasa digunakan oleh industri kimia untuk menurunkan kadar amoniak dalam air limbah yaitu dengan sistem packed bed. Sistem packed bed menggunakan bahan isian (packing) untuk memperluas bidang kontak. Penggunaan alat ini dalam pengolahan lateks skim adalah sebuah terobosan yang diharapkan dapat membantu industri lateks pekat dalam menangani lateks skim. Diharapkan dengan alat ini penurunan kadar amoniak lateks skim dapat dilakukan dengan lebih sederhana, murah dan mudah tetapi mampu memberikan hasil yang memuaskan.

\section{BAHAN DAN METODE}

Bahan yang digunakan dalam penelitian ini adalah lateks skim, sedangkan bahan utama pembuatan menara deammoniasi adalah silinder plastik, bahan isian tipe raschig ring, klem, blower, kayu, seng, besi, pipa pvc, pompa, kran, semen, batu, dan pasir.

Data koefisien transfer massa atau penguapan amoniak dalam lateks skim belum diketahui, karena itu sebelum dilakukan perancangan skala besar perlu dilakukan penelitian skala kecil terlebih dahulu untuk mengetahui koefisien transfer massa amoniak dalam lateks skim.

A. Mencari koefisien transfer massa amoniak dalam lateks skim sebagai 
salah satu data untuk perancangan skala besar.

1. Membuat menara deammoniasi skala kecil (packed tower) yaitu :

a. Tinggi bahan isian $(z): 1,1 \mathrm{~m}$

b. Diameter (D): 0,32 m

c. Bahan isian dibuat sama dengan yang digunakan untuk skala besar yaitu berbentuk raschig ring dengan diameter $50 \mathrm{~mm}$

2. Memasang blower dengan debit udara (G) : 1,7 $\mathrm{m}^{3} /$ menit

3. Menganalisis kadar amoniak awal $\left(\mathrm{C}_{0}\right)$

4. Mengatur debit lateks skim (L) dengan membuka kran pada posisi 1/4, 1/2, 3/4 dan terbuka penuh.

5. Mengukur debit lateks skim dan menganalisis kadar amoniak keluar menara $\left(\mathrm{C}_{\mathrm{e}}\right)$

6. Menghitung koefisien transfer massa amoniak dengan rumus yang dikembangkan oleh Tchobanoglous et al. (2003) sebagai berikut :

a. Menentukan tekanan operasi $\left(\mathrm{P}_{\mathrm{T}}\right)=$ 1 atm dan Tetapan Henry $(\mathrm{H})=$ $0,75 \mathrm{~atm}$

b. Menghitung stripping factor (S) dengan satuan $\mathrm{G}$ dan L dalam gmol $\mathrm{S}=\stackrel{\mathrm{G}}{\mathrm{L}} \mathrm{x}_{\mathrm{T}}^{\mathrm{H}}$

c. Menghitung Number of Transfer Units (NTU)

$\operatorname{NTU}\left[\frac{\mathrm{S}}{\mathrm{S}-1}\right] \ln \left[\frac{(\mathrm{Co} / \mathrm{Ce})(\mathrm{S}-1)+1}{\mathrm{~S}}\right]$

d. Menghitung Height of a Transfer Unit (HTU) dengan satuan meter (m)

$$
\mathrm{Z}=\mathrm{HTU} \times \mathrm{HNU}
$$

e. Menghitung Koefisien transfer massa $\left(K_{L} a\right)$ dengan satuan detik ${ }^{-1}$

$$
\mathrm{HTU}=\frac{\mathrm{L}}{\mathrm{K}_{\mathrm{L}} \mathrm{aA}}
$$

B. Perancangan menara deammoniasi

Metode perhitungan dalam perancangan menara deammoniasi ini mengacu pada Tchobanoglous et al. (2003) dengan variabel-variabel yang digunakan yaitu :

1. Kadar amoniak lateks skim awal $\left(\mathrm{C}_{\mathrm{o}}\right)$ adalah $0,5 \%$

2. Kadar amoniak keluar manara $\left(\mathrm{C}_{\mathrm{e}}\right)$ adalah $0,25 \%$
3. Debit lateks skim maksimum (Qskim) adalah $1500 \mathrm{~L} / \mathrm{jam}$

4. Suhu operasi adalah $20^{\circ} \mathrm{C}$

5. Tetapan Henry $(\mathrm{H})$ sebesar $0,75 \mathrm{~atm}$

6. Tekanan operasi $\left(\mathrm{P}_{\mathrm{T}}\right)$ sebesar $1 \mathrm{~atm}$

7. Asumsi : pengaruh adanya partikel karet diabaikan

Tahapan perhitungan dan persamaan yang digunakan adalah sebagai berikut :

1. Perhitungan kebutuhan udara

a. Menghitung fraksi mol $\left(\mathrm{C}_{\mathrm{i}}\right) \operatorname{amoniak}(\mathrm{A})$ dan air (B) dalam cairan

$c_{A}=\frac{n_{A}}{n_{A}+n_{B}}$

dengan $n$ adalah jumlah gmol

b. Menghitung fraksi mol amoniak keluar menara $\left(\mathrm{y}_{\mathrm{e}}\right)$, dengan indeks e berarti dalam kondisi seimbang.

$y_{\theta}=\frac{H \cdot C_{0}}{P_{T}}$

c. Menghitung perbandingan mol cairan (L) dan udara (G)

$\frac{G}{L}=\frac{P_{T}}{H} \frac{\left(C_{0}-C_{\theta}\right)}{C_{0}}=\frac{\left(C_{0}-C_{\theta}\right)}{C_{0}}$

d. Menghitung rasio volume cairan dan gas

Udara pada suhu $20^{\circ} \mathrm{C}, 1 \mathrm{gmol}=24,1$ liter

Air pada suhu $20^{\circ} \mathrm{C}, 1 \mathrm{gmol}=0,018$ liter

e. Menghitung kebutuhan udara pada kondisi ideal (Qu)

$Q_{u}=\left(\frac{G}{L}\right) Q$ skim

2. Perhitungan dimensi menara deammoniasi

a. Bahan isian dipilih berbentuk raschig ring dengan diameter $50 \mathrm{~mm}$. Packing Factor $\left(\mathrm{C}_{\mathrm{f}}\right) 45$-60, diambil 50 (Tabel 1)

b. Stripping Factor (S)1,5-5, diambil 5 (Tabel 1)

c. Pressure drop $(\Delta P) 100-400$, diambil $300\left(\mathrm{~N} / \mathrm{m}^{2}\right) / \mathrm{m}$ (Tabel 1)

d. Menghitung diameter menara dengan menggunakan grafik

i. Mencari nilai ordinat untuk Stripping Factor $(S)=5$ dengan Persamaan (1) dan persamaan berikut: 
Tabel 1. Parameter disain khusus untuk menara penguapan amoniak Table 1. Typical design parameter of deammoniation tower

\begin{tabular}{|c|c|c|c|}
\hline $\begin{array}{l}\text { Jenis } \\
\text { Item }\end{array}$ & $\begin{array}{l}\text { Simbol } \\
\text { Symbol }\end{array}$ & $\begin{array}{l}\text { Satuan } \\
\text { Unit }\end{array}$ & $\begin{array}{l}\text { Penghilangan amoniak } \\
\text { Ammonia removal }\end{array}$ \\
\hline $\begin{array}{l}\text { Laju alir cairan } \\
\text { Liquid loading rate }\end{array}$ & & $\mathrm{L} / \mathrm{m}^{2} \cdot \min$ & $40-80$ \\
\hline $\begin{array}{l}\text { Rasio udara terhadap cairan } \\
\text { Air to liquid ratio }\end{array}$ & $\mathrm{G} / \mathrm{L}$ & $\mathrm{m}^{3} / \mathrm{m}^{3}$ & $2000-6000: 1$ \\
\hline $\begin{array}{l}\text { Faktor pelucutan } \\
\text { Stripping factor }\end{array}$ & $\mathrm{S}$ & Unitless & $1,5-5,0$ \\
\hline $\begin{array}{l}\text { Penurunan tekanan udara yang diizinkan } \\
\text { Allowable air pressure drop }\end{array}$ & $\Delta \mathrm{P}$ & $\left(\mathrm{N} / \mathrm{m}^{2}\right) / \mathrm{m}$ & $100-400$ \\
\hline $\begin{array}{l}\text { Rasio tinggi terhadap garis tengah } \\
\text { Height to diameter ratio }\end{array}$ & $Z / D$ & $\mathrm{~m} / \mathrm{m}$ & $\leq 10: 1$ \\
\hline $\begin{array}{l}\text { Kedalamaan bahan isian } \\
\text { Packing depth }\end{array}$ & $Z$ & $\mathrm{~m}$ & $2-6$ \\
\hline $\begin{array}{l}\text { Faktor keamanan } \\
\text { Factor of safety }\end{array}$ & $\mathrm{SF}$ & $\% \mathrm{D}, \% \mathrm{Z}$ & $20-50$ \\
\hline $\begin{array}{l}\text { pH limbah cair } \\
\text { Wastewater } p H\end{array}$ & $\mathrm{pH}$ & Unitless & $10,8-11,5$ \\
\hline $\begin{array}{l}\text { Perkiraan faktor bahan isian } \\
\text { Approximate packina factors }\end{array}$ & & & \\
\hline $\begin{array}{l}\text { Approximate packing factors } \\
\text { Pall rings, intalox saddles }\end{array}$ & $\begin{array}{l}\mathrm{C}_{\mathrm{f}} \\
\mathrm{C}_{\mathrm{f}} \\
\mathrm{C}_{\mathrm{f}}\end{array}$ & $\begin{array}{l}12,5 \mathrm{~mm} \\
25 \mathrm{~mm} \\
50 \mathrm{~mm}\end{array}$ & $\begin{array}{c}180-240 \\
30-60 \\
20-25\end{array}$ \\
\hline Berl saddles, Raschig rings & $\begin{array}{l}C_{f} \\
C_{f} \\
C_{f}\end{array}$ & $\begin{array}{l}12,5 \mathrm{~mm} \\
25 \mathrm{~mm} \\
50 \mathrm{~mm}\end{array}$ & $\begin{array}{c}300-600 \\
120-160 \\
45-60\end{array}$ \\
\hline
\end{tabular}

Sumber : Tchobanoglous et al. (2003)

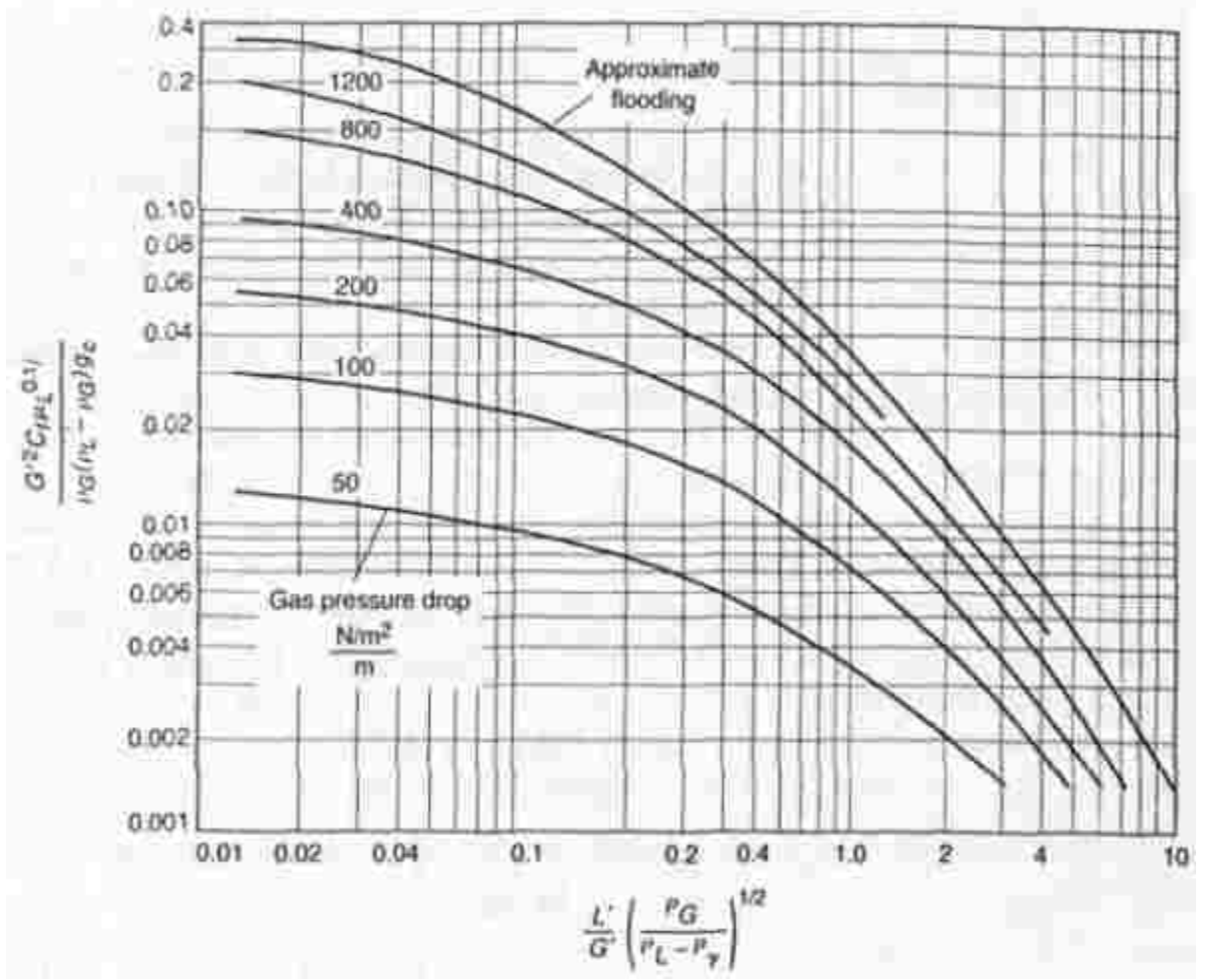

Gambar 2. Grafik untuk perhitungan nilai $\mathrm{G}^{\prime}$

Figure 2. Graphic for calculating $G^{\prime}$ 


$$
\frac{L^{\prime}}{G^{\prime}}\left(\frac{\rho_{G}}{\rho_{L}-\rho_{G}}\right)^{1 / 2} \approx \frac{L^{\prime}}{G^{\prime}}\left(\frac{\rho_{G}}{\rho_{L}}\right)^{1 / 2}
$$

ii. Mencari nilai y dengan grafik (Gambar 2)

iii. Mencari debit cairan dan udara tiap satuan luas ( $\mathrm{G}^{\prime}$ dan $\left.\mathrm{L}^{\prime}\right)$

$$
G^{\prime}=\left[\frac{(\text { nilai } y)\left(\rho_{G}\right)\left(\rho_{L}-\rho_{G}\right)}{\left(C_{f}\right)\left(\mu_{L}\right)^{0,1}}\right]^{1 / 2}
$$

iv. Mencari diameter menara

$$
D=\left[\frac{(4 / \pi)(Q \text { skim })\left(\rho_{l}\right)}{L^{\prime}}\right]^{1 / 2}
$$

e. Mencari Height of a Transfer Unit (HTU) dengan Persamaan (4)

f. Mencari Number of Transfer Units (NTU) dengan Persamaan (2)

g. Mencari tinggi menara dengan Persamaan (3)

C. Pembangunan menara deammoniasi

D. Ujicoba menara deammoniasi

\section{HASIL DAN PEMBAHASAN}

Hasil analisis kadar amoniak sebelum masuk menara deamoniasi adalah 0,5\%, sedangkan debit dan kadar amoniak keluar menara disajikan dalam Tabel 2. Menurut Tchobanoglous et al. (2003), jumlah udara peniup minimum yang digunakan adalah apabila nilai $\mathrm{S}=1$. Apabila $\mathrm{S}<1$ maka jumlah udara yang digunakan kurang memadai atau tidak mencukupi untuk mencapai kondisi yang diinginkan.

Berdasarkan hitungan pada Tabel 2 terlihat bahwa kondisi operasi yang memenuhi persyaratan adalah pada posisi kran terbuka $1 / 4$ atau dengan debit 0,78 $\mathrm{L} /$ menit karena $\mathrm{S}>1$; sedangkan kondisi operasi lainnya memiliki nilai $\mathbf{S}<1$ maka kondisi tersebut tidak memenuhi syarat operasi dan data tersebut tidak dapat digunakan untuk menghitung nilai $\mathrm{K}_{\mathrm{L}} \mathrm{a}$.

Nilai $\mathrm{K}_{\mathrm{L}}$ a dihitung dengan menggunakan persamaan-persamaan yang sesuai yaitu persamaan 1 - 4. Hasil perhitungan untuk kondisi tersebut diperloleh nilai $\mathrm{K}_{\mathrm{L}} \mathrm{a}$ sebesar 2,44.10 det $^{-1}$. Nilai $\mathrm{K}_{\mathrm{L}} \mathrm{a}$ yang diperoleh selanjutnya dapat digunakan untuk desain menara deamoniasi skala besar. Untuk meminimalkan kesalahan maka jenis dan ukuran bahan isian dibuat sama dengan ukuran saat melakukan penelitian skala kecil. Kebutuhan udara minimum dihitung sebagai pembanding terhadap kebutuhan udara operasi riil nantinya. Hasil perhitungan kebutuhan udara minimum disajikan pada Tabel 3.

Dimensi menara deammoniasi dihitung dengan menggunakan persamaanpersamaan perancangan menara deammoniasi yaitu persamaan 1 - 4 dan 9 11. Hasil perhitungan perancangan diperoleh hasil seperti pada Tabel 4. Selanjutnya menara deammoniasi dibuat berdasarkan dimensi hasil perhitungan dalam perancangan, yaitu dengan tinggi

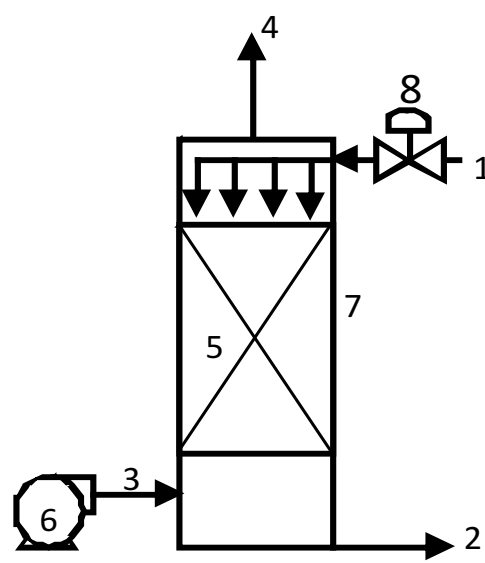

Keterangan gambar (Description):

1. Aliran lateks skim masuk (skim latexinlet)

2. Aliran lateks skim keluar (skim latex outlet)

3. Aliran udara masuk (air inlet)

4. Aliran udara keluar (air outlet)

5. Bahan isian (packing)

6. Blower (blower)

7. Silinder plastik (plastic cylinder)

8. Kran (valve)

Gambar 1. Bagan alat penelitian skala laboratorium

Figure 1. Materials for scale laboratory research scheme 
Tabel 2. Debit lateks skim dan kadar amoniak keluar menara Table 2. Debit of skim latex and ammonia content output

\begin{tabular}{ccccc}
\hline Posisi kran & $\begin{array}{c}\text { Debit } \\
\text { (L/menit) }\end{array}$ & $\begin{array}{c}\text { Kadar amoniak } \\
\text { keluar menara } \\
\text { Ammonia content in } \\
\text { Debit } \\
\text { (L/minute) }\end{array}$ & $\begin{array}{c}\text { Stripping } \\
\text { factor }(\mathrm{S})\end{array}$ & $\begin{array}{c}\text { Uraian } \\
\text { Remarks }\end{array}$ \\
\hline $1 / 4$ & 0,780 & 0,17 & 1,2231 & $\mathrm{~S}>1$ \\
$1 / 2$ & 1,950 & 0,29 & 0,4892 & $\mathrm{~S}<1$ \\
$3 / 4$ & 3,756 & 0,36 & 0,2540 & $\mathrm{~S}<1$ \\
1 (terbuka penuh) & & & 0,1884 & $\mathrm{~S}<1$ \\
$($ Full opened) & 5,064 & 0,37 & & \\
\hline
\end{tabular}

Tabel 3. Hasil perhitungan debit udara minimum Table 3. Calculation of minimum air debit

\begin{tabular}{|c|c|c|c|c|}
\hline No & $\begin{array}{l}\text { Uraian } \\
\text { Remarks }\end{array}$ & $\begin{array}{l}\text { Simbol } \\
\text { Symbol }\end{array}$ & $\begin{array}{l}\text { Hasil hitungan } \\
\text { Calculation }\end{array}$ & $\begin{array}{l}\text { Satuan } \\
\text { Unit }\end{array}$ \\
\hline 1 & $\begin{array}{l}\text { Fraksi mol amoniak dalam lateks skim } \\
\text { umpan } \\
\text { Mol fraction of ammonia in skim latex input }\end{array}$ & $\mathrm{C}_{\mathrm{o}}$ & 0,005662 & $\begin{array}{l}\text { gmol } \mathrm{NH}_{3} / \\
\text { gmol } \mathrm{H}_{2} \mathrm{O}\end{array}$ \\
\hline 2 & $\begin{array}{l}\text { Fraksi mol amoniak dalam lateks skim keluar } \\
\text { Mol fraction of ammonia in skim latex output }\end{array}$ & $\mathrm{C}_{\mathrm{e}}$ & 0,002831 & $\begin{array}{l}\text { gmol } \mathrm{NH}_{3} / \\
\text { gmol } \mathrm{H}_{2} \mathrm{O}\end{array}$ \\
\hline 3 & $\begin{array}{l}\text { Fraksi mol amoniak dalam udara keluar } \\
\text { Mol fraction of ammonia in air output }\end{array}$ & $\mathrm{y}_{\mathrm{e}}$ & 0,004247 & $\begin{array}{l}\text { gmol } \mathrm{NH}_{3} / \\
\text { gmol gas }\end{array}$ \\
\hline 4 & $\begin{array}{l}\text { Rasio udara dan cairan dalam mol } \\
\text { Mol ratio of air and liquid }\end{array}$ & $\mathrm{G} / \mathrm{L}$ & 0,6700 & $\begin{array}{l}\text { gmol gas / } \\
\text { gmol } \mathrm{H}_{2} \mathrm{O}\end{array}$ \\
\hline 5 & $\begin{array}{l}\text { Rasio udara dan cairan dalam volume } \\
\text { Volume ratio of air and liquid }\end{array}$ & $\mathrm{G} / \mathrm{L}$ & 892,5926 & Liter \\
\hline 6 & $\begin{array}{l}\text { Debit lateks skim } \\
\text { Debit of skim latex }\end{array}$ & $\mathrm{L}$ & 0,6944 & $\mathrm{~L} / \mathrm{s}$ \\
\hline 7 & $\begin{array}{l}\text { Debit udara minimum } \\
\text { Minimum debit of air }\end{array}$ & $\mathrm{G}$ & 371,9134 & $\mathrm{~L} / \mathrm{s}$ \\
\hline
\end{tabular}

Tabel 4. Hasil perhitungan dimensi menara deammoniasi Table 4. Calculation of deammoniation tower dimension

\begin{tabular}{|c|c|c|c|c|}
\hline No & $\begin{array}{l}\text { Uraian } \\
\text { Remarks }\end{array}$ & $\begin{array}{l}\text { Simbol } \\
\text { Symbol }\end{array}$ & $\begin{array}{l}\text { Hasil hitungan } \\
\text { Calculation }\end{array}$ & $\begin{array}{l}\text { Satuan } \\
\text { Unit }\end{array}$ \\
\hline 2 & $\begin{array}{l}\text { Rasio lateks skim dan udara dalam berat } \\
\text { Mass ratio of skim latex and air } \\
\text { Kelompok bilangan tak berdimensi (nilai ordinat) } \\
\text { Nondimension unit (value of ordinate) }\end{array}$ & $\begin{array}{c}\mathrm{L}^{\prime} / \mathrm{G}^{\prime} \\
\frac{L^{\prime}}{G^{\prime}}\left(\frac{\rho_{G}}{\rho_{L}}\right)^{1 / 2}\end{array}$ & 0,0083 & $\mathrm{~kg} / \mathrm{kg}$ \\
\hline 3 & Nilai aksis (Gambar 2) (Value of axis (Figure 2) & $\mathrm{Y}$ & 0,07 & - \\
\hline 4 & Kecepatan loading udara (Air loading rate) & $\mathrm{G}^{\prime}$ & 1,8312 & $\mathrm{~kg} / \mathrm{m}^{2} \cdot \mathrm{det}$ \\
\hline 5 & $\begin{array}{l}\text { Kecepatan loading lateks skim } \\
\text { Skim latex loading rate }\end{array}$ & $\mathrm{L}^{\prime}$ & 0,4395 & $\mathrm{~kg} / \mathrm{m}^{2} \cdot \mathrm{det}$ \\
\hline 6 & Debit udara (Air debit) & $\mathrm{L}$ & 1202,831 & $\mathrm{~L} / \mathrm{det}$ \\
\hline 7 & $\begin{array}{l}\text { Diameter menara deammoniasi } \\
\text { Diameter of deammoniation tower }\end{array}$ & $\mathrm{D}$ & 1,0980 & $\mathrm{~m}$ \\
\hline 8 & Jumlah tranfer unit (Height of a transfer unit) & HTU & 1,8020 & $\mathrm{~m}$ \\
\hline 9 & Tinggi tranfer unit (Number of transfer units) & NTU & 0,7347 & - \\
\hline 10 & $\begin{array}{l}\text { Tinggi menara deammoniasi } \\
\text { Height of deammoniation tower }\end{array}$ & $z$ & 1,3240 & $\mathrm{~m}$ \\
\hline
\end{tabular}


Tabel 5. Spesifikasi menara deammoniasi Table 5. Spesification of deammoniation tower

\begin{tabular}{lcc}
\hline \multicolumn{1}{c}{$\begin{array}{c}\text { Spesifikasi } \\
\text { Specification }\end{array}$} & $\begin{array}{c}\text { Dimensi } \\
\text { Dimension }\end{array}$ & $\begin{array}{c}\text { Satuan } \\
\text { Unit }\end{array}$ \\
\hline $\begin{array}{l}\text { Diameter } \\
\text { Diameter }\end{array}$ & 1,1 & $\mathrm{~m}$ \\
$\begin{array}{l}\text { Tinggi tumpukan bahan isian } \\
\text { Height of packing }\end{array}$ & 1,3 & $\mathrm{~m}$ \\
$\begin{array}{l}\text { Ukuran bahan isian } \\
\text { Size of packing }\end{array}$ & 50 & $\mathrm{~mm}$ \\
$\begin{array}{l}\text { Debit udara blower } \\
\text { Air debit of blower } \\
\text { Tekanan udara keluar blower } \\
\text { Air pressure outlet of blower } \\
\text { Daya blower } \\
\text { Power of blower }\end{array}$ & 1250 & L/detik \\
\end{tabular}
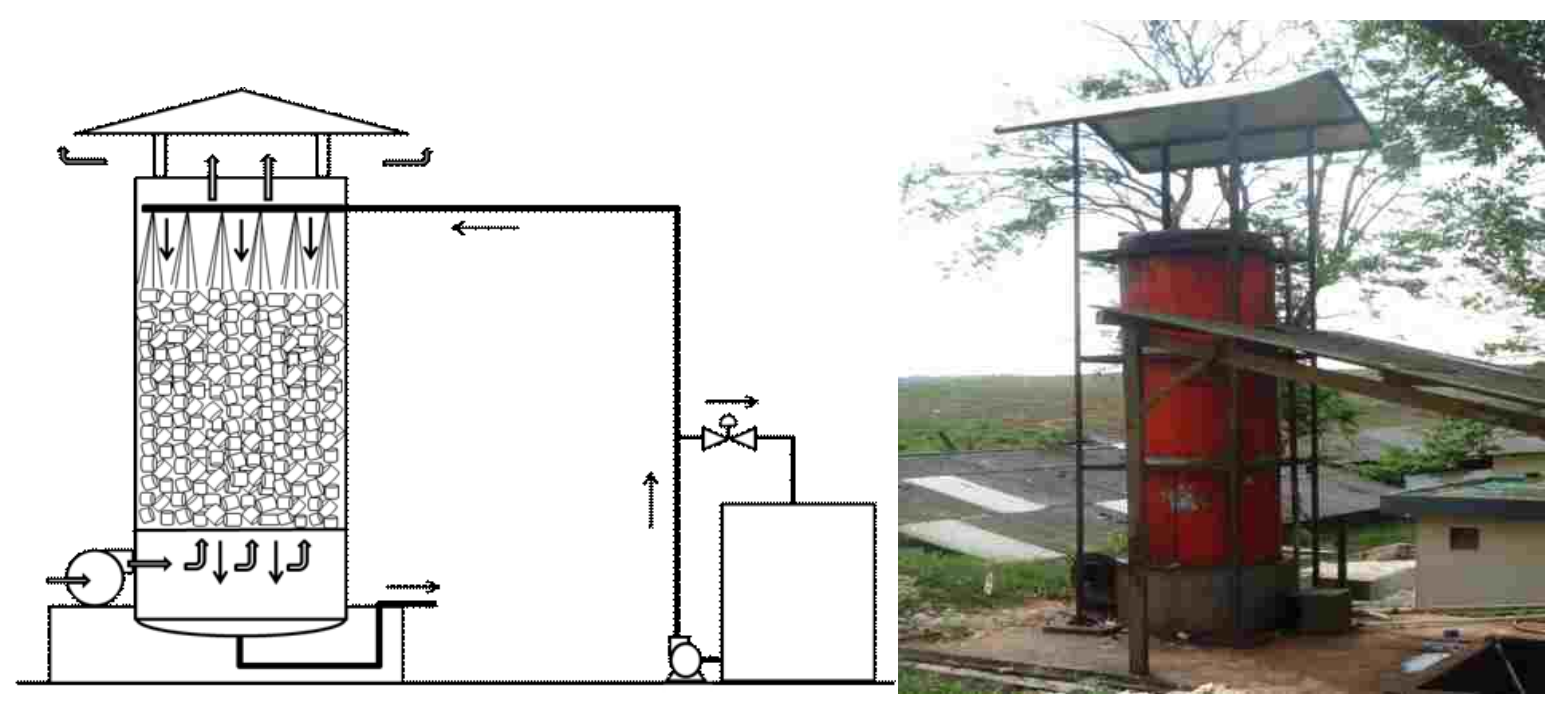

Gambar 3. Sketsa dan foto menara deammoniasi

Figure 3. Sketch and picture of deammoniation tower

bahan isian 1,3 $\mathrm{m}$ dan diameter $1,1 \mathrm{~m}$ seperti pada Gambar 3 dan Tabel 5. Diameter menara disesuaikan dengan ukuran standar yang ada di pasaran dengan ukuran yang paling mendekati. Untuk mengetahui kemampuan menara deammoniasi ini maka dilakukan ujicoba untuk menurunkan kadar amoniak lateks skim.

Rata-rata kadar amoniak lateks skim masuk menara deammoniasi adalah 0,5\%. Dari beberapa ujicoba diketahui bahwa kadar amoniak lateks skim dapat turun sesuai dengan perancangan yaitu berkisar $0,18-0,25 \%$, atau jika dirata-rata sekitar $0,22 \%$. Hal ini berarti persentase amoniak teruapkan rata-rata adalah $56,31 \%$. Hasil ujicoba selengkapnya disajikan pada Tabel 6.

Perbedaan antara perhitungan dengan di lapangan dimungkinkan karena adanya beberapa faktor yang mempengaruhi yaitu:

1. Debit lateks skim yang dapat bervariasi karena pengaturan debit lateks skim masih manual sehingga dimungkinkan 
Tabel 6. Hasil ujicoba menara deammoniasi Table 6. Trial result of deammoniation tower

\begin{tabular}{cccc}
\hline $\begin{array}{c}\text { Hari } \\
\text { Day }\end{array}$ & $\begin{array}{c}\text { Volume lateks skim } \\
\text { Volume of skim latex } \\
\text { L }\end{array}$ & $\begin{array}{c}\text { Konsentrasi } \mathrm{NH}_{3} \text { keluar } \\
\mathrm{NH}_{3} \text { content in output } \\
\%\end{array}$ & $\begin{array}{c}\text { Persentase teruapkan } \\
\text { Percentage removal } \\
\%\end{array}$ \\
\hline 1 & 367 & 0,21 & 58 \\
2 & 2610 & 0,25 & 50 \\
3 & 2610 & 0,18 & 64 \\
4 & 2610 & 0,25 & 50 \\
5 & 2610 & 0,25 & 50 \\
6 & 3870 & 0,20 & 60 \\
7 & 5700 & 0,19 & 62 \\
8 & 4500 & 0,21 & 58 \\
9 & 9000 & 0,21 & 58 \\
10 & 7740 & 0,25 & 50 \\
11 & 6300 & 0,25 & 50 \\
12 & 7110 & 0,19 & 62 \\
13 & 5490 & 0,20 & 60 \\
Rata-rata & 4655,15 & 0,22 & 56,31 \\
Average & 4 & & \\
\hline
\end{tabular}

debit lateks skim lebih kecil dari debit perancangan.

2. Blower yang digunakan secara teoritis memiliki debit $1250 \mathrm{~L} / \mathrm{s}$ atau sedikit lebih banyak dari debit perancangan.

3. Adanya asumsi-asumsi dan penetapan data yang menggunakan metode pendekatan sehingga akurasinya masih terlalu lebar, namun demikian pendekatan-pendekatan dalam perhitungan sudah menghasilkan menara deammoniasi yang kinerjanya tidak begitu jauh dari perhitungan.

Untuk meningkatkan persentase amoniak yang teruapkan dapat ditempuh langkah-langkah sebagai berikut yaitu menambahkan ketinggian bahan isian, karena bahan isian ini masih cukup pendek yaitu hanya $1,3 \mathrm{~m}$. Selain itu dapat juga dengan menaikkan debit udara peniup dan mengurangi debit lateks skim.

Perawatan menara deammoniasi ini relatif mudah. Setelah pemakaian secara terus menerus selama sekitar 6 bulan sebagian karet skim yang menempel pada lapisan permukaan akan menyebabkan aliran udara dan lateks skim menjadi kurang maksimal. Oleh karena itu perlu dilakukan perawatan dengan pembongkaran dan pembersihan menara deammoniasi. Sebaiknya konstruksi menara deammoniasi dibuat sedemikian rupa mudah dibongkar pasang, sehingga akan memudahkan dan mempercepat pembersihannya.

\section{KESIMPULAN}

Menara deammoniasi dengan sistem packed bed memiliki diameter $1,1 \mathrm{~m}$, ketinggian bahan isian 1,3 $\mathrm{m}$ dan dapat menurunkan kadar amoniak dari 0,50\% menjadi $0,22 \%$. Menara deammoniasi ini relatif mudah dibuat, dan mudah dalam perawatannya. Untuk mendapatkan kadar amoniak yang lebih rendah dapat dilakukan dengan menambah ketinggian bahan isian, menaikkan debit udara peniup atau menurunkan debit lateks skim. 


\section{UCAPAN TERIMA KASIH}

Terima kasih diucapkan kepada Dadi Rusadi Maspanger, Ary Achyar Alfa dan Uhendi Haris atas saran dan masukannya selama pelaksanaan perancangan menara deammoniasi ini.

\section{DAFTAR PUSTAKA}

Alfa, A.A., D. Suparto, S. Honggokusumo, dan O. Siswantoro. 1998. Pemanfaatan karet skim berkualitas tinggi sebagai bahan baku gelang karet. J. Penel. Karet, 16 (1-3), 2235.

Blackely, D.C. 1966. High Polimer Latices. Volume I : Fundamental Principles, Their Science and Technology. Maclaren, London.

Haris, U., H. Prastanto, A.A. Alfa, and D.R. Maspanger. 2010. The Economic potential of skim latex processing on latex concentrate industry: Indonesian Case. Preprint of Proc. IRRDB Int. Rubb. Conf. 2010, Hainan, 19 October 2010. International Rubber Research Development Board.
Noordin bin Abd. Kadir Bakti, 1993. Rotating-Disc system for deammoniation of skim latex. Planters' bulletin, 2(215), 47-51.

Solichin, M. dan A. Anwar, 2008. Penggunaan asap cair dalam pengolahan blok skim. J. Penel. Karet, 26 (1), 84-97.

Tchobanoglaus, G., F.L. Burton, and H.D. Stense1. 2003. Wastewater Engineering Treatment and Reuse, Metcalf and Eddy,inc, $4^{\text {th }}$ edition, McGraw-Hill Companies, New York. 